\title{
Examination of the Compatibility of the Questions Used by Social Studies Teachers in the Class with the Program Achievements According to the SOLO Taxonomy*
}

\author{
Yusuf Keskin $^{1}$, Sevgi C. Keskin ${ }^{2}$, Ayşegül Kırtel ${ }^{3}$ \\ "This study was submitted as verbal statement in International Symposium on Social Studies Education IV, which was \\ held in Bolu Abant Izzet Baysal University in Turkey on 23-25 April 2015 \\ ${ }^{2,3}$ Associate Professor, Department of Social Studies Education, Faculty of Education, Sakarya University, Hendek, \\ Sakarya, Turkey \\ ${ }^{4}$ Research Assistant, Department of Social Studies Education, Faculty of Education, Sakarya University, Hendek, \\ Sakarya, Turkey \\ Correspondence: Yusuf Keskin, Department of Social Studies Education, Faculty of Education, Sakarya University, \\ Hendek, 54300 Sakarya, Turkey
}

Received: January 7, 2016 Accepted: January 15, 2016 Online Published: January 20, 2016

doi:10.11114/jets.v4i4.1286 URL: http://dx.doi.org/10.11114/jets.v4i4.1286

\begin{abstract}
The purpose of this study is to examine the compatibility of the questions used by the social studies branch teachers in the level of $6^{\text {th }}$ and $7^{\text {th }}$ grade with the achievements included in the teaching program. Structure of observed learning outcome (SOLO) taxonomy, which was presented by Biggs and Colis (1982) as an alternative to Bloom's cognitive domain classification, is used for this examination. The research has been complied with the 'case study' qualitative research pattern, and observation and document analysis technique was used. Four teachers were observed at the level of sixth grade and three teachers were observed at the level of seventh grade. At the level of sixth grade, one teacher was observed within the first unit, the others in the second unit; and at the level of seventh grade, three teachers were observed within the second unit. It was discovered at the end of the research that questions asked by the teachers in the class complied with the uni-structural and multi-structural levels although most of the relevant achievements given in the program corresponded to the relational structure level according to the SOLO taxonomy. Results of this study show that the SOLO taxonomy can be used effectively both in the teaching programs and during the learning-teaching process.
\end{abstract}

Keywords: SOLO taxonomy, questioning skills, social studies teaching program, achievements of the social studies course, social studies teachers

\section{Introduction}

The social studies course is an interdisciplinary course bringing together the social science disciplines through integration (Barth \& Demirtaş, 1997; Sönmez, 1997). With this appearance so far, great importance has been given to this course for the purpose of training good and responsible citizens (Erden, 2000; Keskin, 2002). Constructive understanding was adopted in the new social studies teaching program, which was put into practice in 2005 by the National Ministry of Education; the program was designed keeping the students and activities central within its execution (MEB [NME], 2005; Keskin, 2008).

Achievements, instead of goal expressions, were included in the renewed social studies teaching program, but differently from the old programs. Even though goals and achievements seem equivalent to each other functionally, it is seen that achievements are quite different from the goal expressions. Goals in the previously applied programs focused mostly on low-level mental skills, and with this view, it was exhibiting an appearance far from both the general goals of the course and the realization of the general objectives of the Turkish national education (Keskin, 2002). Goal or achievement expressions in a program must include both low- and high-level thinking skills in a balanced way, because it is not possible to shift to the high-level without gaining the low-level thinking skills (Biggs, 2003; Gezer \& İlhan, 2014). 
The cognitive domain taxonomy, which was presented by Bloom (1956), has been used in the teaching programs prepared in Turkey so far (Demirel, 2015). Although this taxonomy has been used and known for years, it is not possible to say that it is completely understood by both pedagogues and teachers. It was not written in the previous social studies teaching programs at which steps the goals appear as per the cognitive domain classification. This brought out some problems within the implementation field. Moreover, there are wrong questions related to this topic in the educational sciences tests or KPSS (one of public personnel selection examinations in Turkey), which are prepared by pedagogues. Usage of the cognitive domain classification, which cannot be explained in the programs as required nor exactly divided into steps by pedagogues and teachers, is criticized by many researchers today (Ay, 2005; Ayvac1 \& Türkdoğan, 2010; Tutkun, 2012; Yüksel, 2007).

Criticisms of Bloom's (1956) classification caused the emergence of new and alternative taxonomies regarding the cognitive domain. The mostly known taxonomies among them are 'Structure of the Observed Learning Outcomes' or SOLO (1982), Haladyana (1997), Fink (2003), Anderson (2001) [Revised Bloom's Taxxonomy], and Marzano (2000). Among these, the SOLO taxonomy is internationally the best-known and accepted taxonomy in addition to Bloom's (Arl, 2013). Conducted studies show that this taxonomy eliminates most of the step division problems present in Bloom's classification and it is better understood by the teachers (Hattie \& Purdie, 1998; Marzano, 2000; Tutkun, Demirtaş, Arslan \& Gür Erdoğan, 2015).

SOLO taxonomy was presented by Biggs and Collis (1982) and is formed of five hierarchical levels as pre-structural, uni-structural, multi-structural, relational and extended abstract stages (Biggs \& Collis, 1982; Biggs \& Collis, 1991; Biggs, 1995; Burnett, 1999a; Burnett, 1999b; Wong, 2007). Students cannot exhibit what is expected from them at the pre-structural level, which is the first step of the SOLO taxonomy. Students receive information at this stage, but this information is unsystematic and non-constructed. Accordingly, no learning can be mentioned at this stage in relation to the topic (Biggs \& Collis, 1982; Burnett, 1999a). Students handle the information with a narrow and superficial viewpoint at the uni-structural level, which is the second step. Students focus on the topic they will study but approach the topic uni-structurally. At this stage, students can use definitions, terminology and names (Brabrand \& Dahl, 2009; Wong, 2007). Students approach a case or situation from various aspects at the multi-structural level, the third step, but cannot build relations between them. In other words, students cannot see the forest while seeing the trees; they cannot perceive the whole (Brabrand \& Dahl, 2009). The uni-structural and multi-structural levels are mostly related to obtaining information. Students obtain the information at these two stages but cannot build relations and think at a high-level. These two steps are a pre-requisite for the realization of the high-level steps (Biggs \& Collis, 1982). At the relational level, the fourth step, students combine the information pieces obtained at the multi-structural stage. In this way, they associate and analyze the information and reach the synthesis. At this stage, in reference to the earlier analogy, students understand how trees could form a forest (Brabrand \& Dahl, 2009; Burnett, 1999b). At the extended abstract level, which is the fifth and the last step, students generalize the obtained meaning/information and transfer it to different areas. They can form hypotheses and theories. Students reach the metacognition level at this step (Brabrand \& Dahl, 2009; Burnett, 1999b).

Although it seems easy to distinguish the five steps of the SOLO taxonomy given above from each other, it is very difficult. Many studies mention verb examples that were given for these levels, which are grounded on the SOLO taxonomy (Ar1, 2013; Brabrand \& Dahl, 2009; Gezer \& İlhan, 2014). It is understood that these verbs were given by Biggs (2003), one of the theorists that presented the taxonomy, for the first time. The indicative verbs written for the levels by Biggs (2003: 80) are given in the table (Table 1) below collectively.

Table 1. Indicative verbs that fit the levels of the SOLO taxonomy.

\begin{tabular}{llll}
\hline Unistructural & Multistructural & Relational & Extended Abstract \\
\hline Memorize & Classify & Apply & Theorize \\
Identify & Describe & Integrate & Hypothesize \\
Recognize & List & Analyze & Generalize \\
Count & Report & Explain & Reflect \\
Define & Discuss & Predict & Generate \\
Draw & Illustrate & Conclude & Create \\
Find & Select & Summarize & Compose \\
Label & Narrate & Review & Invent \\
Match & Compute & Argue & Originate \\
Name & Sequence & Transfer & \\
Quote & Outline & Make a plan & \\
\hline
\end{tabular}

The verb examples given in Table 1 are the key expressions to determine what level that the goals/achievements in the programs and questions used in the course books and courses correspond to within the SOLO taxonomy (Biggs, 2003). Because there is no learning related to the topic at the pre-structural level, there are no verb examples from this step. 
When the researches on the SOLO taxonomy are considered worldwide, the presence of theoretical studies, which compare the SOLO taxonomy with the other taxonomies, draws attention within the applied studies in the fields of mathematics, biology and language teaching (Chan, Tsui, Chan \& Hong, 2002). When the studies conducted on this topic in our country are reviewed, they appear to be parallel with the ones conducted worldwide. Ar1 $(2011 ; 2013)$ approached the SOLO taxonomy including it within the other classifications and examined the taxonomies comparatively in his studies. Ardiç, Yılmaz and Demir (2012), Göktepe and Özdemir (2013) and Bağdat and Anapa Saban (2014) conducted researches including the SOLO taxonomy in terms of math teaching and Gezer and İlhan's (2014) studies also included it in terms of citizenship and democracy education.

Both domestic and foreign studies conducted on the SOLO taxonomy indicate that the classification can be adapted to many courses and situations. The purpose of this study is to examine the compatibility level of the questions used by the social studies branch teachers in the class with the achievements included in the teaching program within the context of the SOLO taxonomy.

\section{Method}

This study was conducted as a case study, which is one of the qualitative research patterns. Observation and document analysis technique was used in this pattern. In the observation method, the researcher observes the area, which is the subject of the research, the occasions, processes and people in the area distantly or as a part of the occasion with an inner viewpoint (Güler, Halıcıoğlu \& Taşğın, 2013; Yıldırım \& Şimşek, 2006). Observations were made within the scope of 'School Experience' courses of the senior students (prospective teachers) who studied in the department of Social Studies Teaching in Sakarya University during the first semester of the academic year of 2014-2015. The fourth activity conducted within the scope of this course is related to questioning. Prospective teachers observe the teacher for one course hour and record in writing all the questions addressed by the teacher to the students.

A three-stage path was followed while conducting this study. These stages are:

1. Observation: Prospective teachers made observation in the class at this stage.

2. Document Analysis: At this stage, relevant unit achievements in the social studies teaching program and questions, which were asked by the teachers in the class, were analysed.

3. Comparison: At this stage, the relevant achievements in the social studies program and teacher questions were compared to each other in the context of the SOLO taxonomy.

Seven different teachers in seven different schools were observed by three prospective teachers within the same course hour at the first stage of the study. Prospective teachers were trained so that reliability in the observations can be ensured. In researches conducted through observation, the notes taken during the observation are the main data sources (Güler, Halıcıoğlu \& Taşğın, 2013). Therefore, three prospective teachers sat in different parts of the classroom during the observation and recorded in writing the questions asked by the teacher without seeing each other. The aim in this implementation is to increase the validity and reliability of the observation through 'researcher diversification', because researcher diversification can be used not only at the analyzing stage, but also during the data collection (in techniques such as observation and interview) stage (Patton 1999; rel. Güler, Halıcıoğlu \& Taşğın, 2013).

At the level of sixth grade, four teachers, and at the level of seventh grade, three teachers were observed. At the level of sixth grade, one teacher was observed within the first unit (I am Learning Social Sciences), the others in the second unit (Life on Earth); moreover, at the level of seventh grade, three teachers were observed within the second unit (Population in Our Country). Therefore, research data were limited to the aforementioned three units. Then, observation records were comparatively examined and the questions commonly recorded by three prospective teachers were determined. The questions which were recorded by one or two prospective teachers were eliminated.

At the second stage of the research, document analysis technique was applied to examine the achievements in the relevant units included in the social studies program and questions asked by the teachers in the class as per the SOLO taxonomy. Not all the achievements in the social studies program, but only the achievements in the observed units were subjected to analysis. Questions asked by the teachers in the class and the achievements were analysed according to the four levels of the SOLO taxonomy (uni-structural, multi-structural, relational and extended abstract). In this analysis, two experts worked independently from each other. After the analysis, the levels determined by the experts for the questions and achievements were compared. While all the achievements were found in compliance with each other, a difference was discovered in two questions among the teacher questions. The questions which were found different were shown to a third expert and an agreement was reached in line with the opinion of the expert. The main purpose behind the conduction of the analysis by two different researchers and then consulting a third expert for the disagreed questions is to increase the validity and reliability through 'researcher diversification'.

At the third and last stage of the research, the achievements in the program and teacher questions were compared. In the 
comparison procedure, the levels of the SOLO taxonomy were considered as the base and the consistency between the achievement levels in the program and the levels of the questions asked by the teachers in the class was examined.

\section{Results}

Research findings are given under this title. The SOLO taxonomy levels of firstly the achievements in the relevant units included in the social studies program and secondly the questions asked by the teachers were discussed and the consistency between both (achievements and question levels) was checked.

\subsection{SOLO Taxonomy Levels of the Relevant Unit Achievements in the Program}

As mentioned in the method section, the SOLO taxonomy levels of the achievements not in all the units that are given in the social studies program, but only the units including observation were analysed. The findings reached as a result of this analysis are shown in Table 2.

Table 2. SOLO taxonomy levels of the relevant unit achievements in the social studies program

\begin{tabular}{|c|c|c|c|c|c|c|c|}
\hline \multirow[b]{2}{*}{ Grade } & \multirow{2}{*}{$\begin{array}{l}\text { Learning } \\
\text { Domain }\end{array}$} & \multirow[b]{2}{*}{ Unit } & \multicolumn{4}{|c|}{ SOLO Taxonomy Level } & \multirow{2}{*}{$\begin{array}{c}\text { Total } \\
\text { Achievemen } \\
\mathbf{t}\end{array}$} \\
\hline & & & Unistructural & $\begin{array}{c}\text { Multistructur } \\
\text { al }\end{array}$ & $\begin{array}{c}\text { Relationa } \\
1\end{array}$ & $\begin{array}{c}\text { Extended } \\
\text { Abstract }\end{array}$ & \\
\hline \multirow{2}{*}{$6^{\text {th }}$} & $\begin{array}{c}\text { Individual and } \\
\text { Society }\end{array}$ & $\begin{array}{c}\text { I am learning } \\
\text { Social } \\
\text { Sciences } \\
\end{array}$ & 2 & 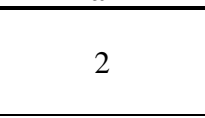 & $x_{1}$ & 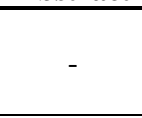 & 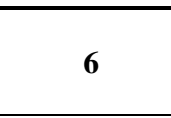 \\
\hline & $\begin{array}{c}\text { People, Places } \\
\text { and } \\
\text { Environments }\end{array}$ & Life on Earth & - & 1 & 6 & - & 7 \\
\hline \multirow[t]{2}{*}{$7^{\text {th }}$} & $\begin{array}{c}\text { People, Places } \\
\text { and } \\
\text { Environments }\end{array}$ & $\begin{array}{l}\text { Population in } \\
\text { Our Country }\end{array}$ & - & 2 & 3 & - & 5 \\
\hline & & & 2 & 5 & 11 & - & 18 \\
\hline
\end{tabular}

It was seen in three units analysed according to the SOLO taxonomy above that there were 18 achievements in total, more than half of these achievements (10 achievements) were at the relational level, one-third (6 achievements) were at the multi-structural level and 2 achievements were at the unistructural level. No achievements were determined at the extended abstract level.

The examples of these achievements are given as a table (Table 3) below. The purpose in this table is to explain the route followed while determining the SOLO levels of the achievements. While determining these achievements, an attempt was made to favour the ones which will be analysed in terms of consistency with the teacher questions in the future.

Table 3. Achievement examples according to SOLO taxonomy levels

\begin{tabular}{|c|c|c|c|c|}
\hline $\begin{array}{l}\text { SOLO } \\
\text { Level }\end{array}$ & Ach.No. & Grade & Unit & Achievements \\
\hline \multirow{2}{*}{ 莗 } & 1 & $6^{\text {th }}$ & $\begin{array}{l}\text { I am learning Social } \\
\text { Sciences }\end{array}$ & $\begin{array}{l}\text { Notice the multi-dimensionality of an occasion by taking an } \\
\text { example from the immediate environment into account. }\end{array}$ \\
\hline & 2 & $6^{\text {th }}$ & $\begin{array}{l}\text { I am learning Social } \\
\text { Sciences }\end{array}$ & $\begin{array}{l}\text { Notice the contribution of the social studies into their development } \\
\text { as active citizens of the Turkish Republic. }\end{array}$ \\
\hline \multirow{2}{*}{ 恶焉 } & 3 & $6^{\text {th }}$ & $\begin{array}{l}\text { I am learning Social } \\
\text { Sciences }\end{array}$ & $\begin{array}{l}\text { Give examples for the implementations conducted by Atatürk for } \\
\text { the development of the social sciences in our country. }\end{array}$ \\
\hline & 4 & $6^{\text {th }}$ & Life on Earth & $\begin{array}{l}\text { Make deduction about the factors that influence the settlement } \\
\text { through sample examinations by beginning from the first } \\
\text { pre-historical settlements until today. }\end{array}$ \\
\hline \multirow{2}{*}{ 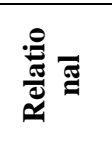 } & 5 & $7^{\text {th }}$ & $\begin{array}{l}\text { Population in Our } \\
\text { Country }\end{array}$ & $\begin{array}{l}\text { Discuss the causes and results of the population distribution in } \\
\text { Turkey with the help of visual materials and data. }\end{array}$ \\
\hline & 6 & $6^{\text {th }}$ & $\begin{array}{l}\text { I am learning Social } \\
\text { Sciences }\end{array}$ & using the scientific research steps. \\
\hline
\end{tabular}

The students are requested to 'notice the multi-directionality of an occasion through an example' in the first achievement and 'notice the contribution of the social studies to their own development with respect to citizenship' in the second achievement; they are requested to think uni-directionally. Further, the achievements are compatible with the verb 'recognize' (See Table 1) given for this level of the SOLO taxonomy. In the third achievement of the multi-structural level, students are asked to give examples that fit for the topic. Students must approach the topic in a multi-directional way to produce examples, but they are not expected to make association. In the fourth achievement again from this level, the students are expected to make deduction in relation to the topic. This achievement resembles the verb 'deduce' given for this level in Table 1. Moreover, students must have a multi-directional viewpoint to make deduction about the factors that influence the settlement. At the relational level, students are expected to combine, 
associate the information pieces they obtain at the multi-structural stage, and reach a synthesis. Students are requested to discuss the causes and results of the population distribution in the fifth achievement of this structural level and expected to associate the causes and results. Plus, the verb 'discuss' is one of the key verbs that indicate this level. In the last achievement, students are requested to make research that fit with the scientific research steps. Students must associate more than one information piece while making research, and reach a synthesis.

\subsection{SOLO Taxonomy Levels of the Questions Asked by Teachers}

As mentioned in the method section, at the level of sixth grade, four teachers, and at the level of seventh grade, three teachers were observed. At the level of sixth grade, one teacher was observed within the first unit (I am Learning Social Sciences), the others in the second unit (Life on Earth); moreover, at the level of seventh grade, three teachers were observed within the second unit (Population in Our Country). The findings obtained as a result of the analysis of these observation data are given separately on the basis of the two grades below.

As a result of the analysis of the data obtained at the level of sixth grade, the table (Table 4) that shows the SOLO taxonomy levels of the questions asked by the teachers in the class is given below.

Table 4. Distribution of the questions asked at the level of sixth grade according to SOLO taxonomy levels ${ }^{1}$

\begin{tabular}{|c|c|c|c|c|c|c|c|c|}
\hline \multirow[b]{2}{*}{ Teacher } & \multirow[b]{2}{*}{$\begin{array}{c}\text { Unit } \\
\text { No }\end{array}$} & \multirow{2}{*}{$\begin{array}{c}\text { Relevant } \\
\text { Ach. } \\
\text { Number }\end{array}$} & \multirow[b]{2}{*}{ Ach.SOLO Level } & \multicolumn{4}{|c|}{ SOLO Taxonomy Level of Questions } & \multirow[b]{2}{*}{ Total } \\
\hline & & & & Unistructural & Multistructural & Relational & $\begin{array}{c}\text { Extended } \\
\text { Abstract }\end{array}$ & \\
\hline $\mathbf{A}$ & 1 & 1 & Multistructural & 4 & 1 & - & - & 5 \\
\hline B & 2 & 4 & $\begin{array}{l}\text { Relational (3), } \\
\text { Multistructural (1) }\end{array}$ & 7 & 2 & - & - & 9 \\
\hline $\mathbf{C}$ & 2 & 1 & Relational & 12 & 7 & - & - & 19 \\
\hline D & 2 & 1 & Relational & 13 & 8 & - & - & 21 \\
\hline & & Total & & 36 & 18 & - & - & 54 \\
\hline
\end{tabular}

When Table 4 is reviewed, it is seen that the questions asked by the four teachers at the sixth grade level in the class are not compatible with the achievement levels in the program. Although most of the achievements are at the relational level of the SOLO taxonomy, the number of questions is quite limited at this level. The least number of questions were asked by $\mathrm{A}$ and $\mathrm{B}$, most of the questions was asked by $\mathrm{C}$ and $\mathrm{D}$. While teacher $\mathrm{A}$, who asked the least number of questions, tried to provide an achievement (Achievement numbered 3 in Table 3) at the multi-structural level in the class, he/she asked 4 questions at the uni-structural level and only 1 question at the multi-structural level. When all of these questions are examined, it is seen that they focus on Atatürk's life (What comes to your mind when Atatürk is mentioned? When did the War of Independence end? etc.) and they are not compatible with the achievement. Even if the question is 'Well, what should be done for the development of the country?', which is compatible with the multi-structural level, it is a question example that has no relation with the achievement.

In the class, teacher B addressed his/her students questions related to four achievements in the unit. Three of these achievements are at the relational level and one of them is at the multi-structural level. Most of the questions asked by the teacher are at the uni-structural level. When these questions are reviewed (What is mathematical position? What bosphoruses are there in Turkey? etc.), it is understood that students are requested to approach the topic uni-directionally. For two questions at the multi-structural level, students are expected to make deductions. When the SOLO levels of the addressed questions are considered, it can be said that their effects on helping the students to fulfil the achievement are weak.

Teacher $\mathrm{C}$ addressed questions for the achievement 'Make deduction about the climatic features through the human experiences in different environments of the world'. At the relational level (19 questions). More than half of these questions are at the uni-structural level (12 questions) and the rest of the 7 questions are at the multi-structural level. Questions asked by the teacher are directly related to the achievement. However, asking questions only at uni-structural and multi-structural levels is not enough to help the students with fulfilling the achievement. A hierarchical order must be followed beginning from the low-level questions towards the high-level ones to help the students with fulfilling the high-level achievements. But the teacher began with the low-level and could not reach the high-level.

Teacher D asked the students 21 questions in total for the achievement 'Make deduction about the factors that influence the settlement through sample examinations by beginning from the first pre-historical settlements until today' at the relational level. Most of these questions (13 questions) are at the uni-structural level and the rest of the questions (8 questions) are at the multi-structural level. The questions asked by this teacher were at the first two levels and did not fit for the achievement level.

\footnotetext{
1 Teachers are shown with letters (A, B, C etc.) in the table. Because the questions asked by some teachers in the class are related to more than one achievement, it was preferred to give this information in the table.
} 
Table 5. Distribution of the questions asked at the level of seventh grade according to SOLO taxonomy levels

\begin{tabular}{|c|c|c|c|c|c|c|c|c|}
\hline \multirow[b]{2}{*}{ Teacher } & \multirow[b]{2}{*}{$\begin{array}{c}\text { Unit } \\
\text { No }\end{array}$} & \multirow{2}{*}{$\begin{array}{c}\text { Relevant } \\
\text { Ach. } \\
\text { Number }\end{array}$} & \multirow[b]{2}{*}{ Ach.SOLO Level } & \multicolumn{4}{|c|}{ SOLO Taxonomy Level of Questions } & \multirow[b]{2}{*}{ Total } \\
\hline & & & & Unistructural & Multistructural & $\begin{array}{c}\text { Relationa } \\
\text { l }\end{array}$ & $\begin{array}{c}\text { Extended } \\
\text { Abstract }\end{array}$ & \\
\hline $\mathbf{E}$ & 2 & 1 & Relational & 11 & 5 & - & - & 16 \\
\hline $\mathbf{F}$ & 2 & 1 & Multistructural & 6 & 1 & - & - & 7 \\
\hline $\mathbf{G}$ & 2 & 4 & $\begin{array}{c}\text { Relational (3), } \\
\text { Multistructural (1) }\end{array}$ & 7 & - & - & - & 7 \\
\hline & & Total & & 24 & 6 & - & - & 30 \\
\hline
\end{tabular}

When Table 5 is considered, two-thirds (4 achievements) of the questions asked at the level of seventh grade within the research are at relational levels and one-third ( 2 achievements) are at multi-structural levels. Whereas most of the achievements are at the relational level, the questions used by teachers in the class were mainly at uni-structural and multi-structural levels.

Teacher E asked the students 11 questions at the uni-structural level and 5 questions at the multi-structural level for the achievement at the relational level ( $5^{\text {th }}$ achievement in Table 3$)$. For the achievement, students are expected to associate and discuss causes and results of the population distribution in our country with the help of visual materials and data. However, students are requested to think mostly uni-directionally with the questions (What does green signify in the map? Which region has the most population? etc.) asked in the class. With the questions that require thinking multi-directionally (Why does Sinop have a low amount of population? Why does Marmara Region have a high amount of population? etc.), students are mostly expected to give an explanation. It can be said with this appearance that the questions will not be so effective in helping the students to fulfil the achievement.

Teacher F asked questions (6 questions) mostly at the uni-structural level for the achievement 'Interpret the data related to the characteristics of the population in our country with the help of tables and graphics' at the multi-structural level. For the achievement, the students are expected to make deduction directly from the information given, but not requested to make association or comparison. Only 1 question is compatible with the achievement level. This question is 'What can be the reasons of the low amount of population in the South Hemisphere?'.

Teacher $\mathrm{G}$ asked questions in the class regarding the 4 achievements in the unit. Three of these achievements are at the relational level and one of them is at the multi-structural level. While the achievements are at higher levels of the SOLO taxonomy, the teacher asked questions only at the uni-structural level in the class. These are simple questions like 'What is agricultural population density?', 'What is population?' and 'What is brain drain?', which measure the information memorized by students. With this appearance, the questions used in the class are quite insufficient to help students to fulfil the achievement.

\section{Discussion}

This study aimed at examining the compatibility level of the questions used by the social studies branch teachers in the class with the achievements included in the teaching program within the context of the SOLO taxonomy. The first finding discovered after the study was the fact that most of the relevant unit achievements included in the social studies teaching program were at the relational level. Instead of the goals given in the previous programs, achievements were included in the new social studies teaching program, which was put into practice in 2005. It is known that the goals given in previous social studies programs mostly dealt with low-level mental skills (Keskin, 2002). Biggs (2003) and Gezer and İlhan (2014) state in their research that goal/achievement expressions in a program must include the low- and high-level thinking skills in a balanced way. Although the achievements in three units, which were examined in this research, were mostly at the relational level according to the SOLO taxonomy, examples of low-level achievements were also determined. The balance status between the low- and high-levels will be presented in a healthier way in the coming studies which will examine the achievements included in the whole social studies program. Thus, Gazel and Erol (2012) and Şenses (2008) stated in their studies focusing on Bloom's taxonomy and the level of class that there was a balance between the low- and high-level steps in the new social studies program and course books.

The second important finding obtained as a result of the research puts forth that the questions used by the social studies branch teachers in the class were mostly at uni-structural and multi-structural levels according to the SOLO taxonomy. Within the scope of the study, four teachers at the level of sixth grade and three teachers at the level of seventh grade were observed. At the level of sixth grade, one teacher was observed within the first unit (I am Learning Social Sciences), the others in the second unit (Life on Earth); moreover, at the level of seventh grade, three teachers were observed within the second unit (Population in Our Country). At the level of sixth grade, four teachers asked students 54 questions in the class. $36(66 \%)$ of these questions are at the uni-structural level and $18(34 \%)$ are at the multi-structural level. No questions were discovered at relational and extended abstract levels. At the level of seventh grade, three teachers asked their students 30 questions in total. Four-fifths (24 questions, 80\%) of these questions are at 
uni-structural levels and the remaining one-fifth (6 questions, 20\%) are at multi-structural levels. No question examples were discovered at relational and extended abstract levels at this grade, similarly to the sixth grade. Hence, Gelen (2002), Dindar and Demir (2006), Koray, Altunçekiç and Yaman (2005) and Ayvacı and Türkdoğan (2010) discovered in their studies that questions asked by the teachers in the class and exams were mostly at low-level steps (information and comprehension) of Bloom's taxonomy. SOLO levels of the questions asked by the social studies teachers in the class are compatible with the cognitive domain steps in these studies and show that teachers generally ask questions for the use of low-level thinking skills in the class and exams.

The third and last finding obtained as a result of the research is the fact that the SOLO taxonomy levels of the achievements included in the social studies program were not compatible with those of the questions used by the social studies branch teachers in the class. $11(61 \%)$ of the 18 achievements in total, which belong to the relevant units examined within the scope of the study, were at the relational level, $5(28 \%)$ were at the multi-structural level and only $2(11 \%)$ were at the uni-structural level of the SOLO taxonomy. Whereas the vast majority of the relevant achievements are at the relational level, the fact that the questions asked by teachers in the class were at uni-structural and multi-structural levels points at the inconsistency between the achievements and questions according to the SOLO taxonomy. Gezer and İlhan (2014) concluded in their study examining the consistency of the achievements, which were included in the program of the citizenship and democracy education course, and the evaluation questions in the course books in terms of the SOLO taxonomy that the compatibility between both of them (program and course book) was low. The result of this research supports the finding obtained in the present research which was conducted for the social studies course.

This study is a restricted study conducted on three units in the social studies program with seven teachers. It is a beginning for more extensive studies which will examine the whole social studies program, course books, exams conducted and questions asked by the teachers in the class as per the SOLO taxonomy in the future. Results of this study show that the SOLO taxonomy is a quite useful and practical classification to analyze both teaching programs and questions in respect of thinking skills.

\section{References}

Anderson, L, W., Krathwohl, D., (Eds). Airasian, P. V., Cruikshank, K. A., Mayer, R. E., Pintrich, P. R., Raths, J., \& Wittrock, M. C. (2001). A taxonomy for learning, teaching, and assessing: A revision of Bloom's taxonomy of educational objectives. New York: Longman.

Ardıç, E. Ö., Yılmaz, B., \& Demir, E. (2012). Examination of primary education $8^{\text {th }}$ grade students's statistical literacy levels about the measures of central tendency and dispersion according to the SOLO taxonomy. Paper presented in X. National Science and Mathematics Education Congress in Niğde University, Niğde, Turkey, June 27 to 30, 2012.

Ar1, A. (2011). Finding acceptance of Bloom's revised cognitive taxonomy on the international stage and in Turkey. Educational Sciences: Theory \& Practice, 11(2), 749-772.

Arı, A. (2013). Revised Bloom, SOLO, Fink, Dettmer taxonomies in cognitive area classification and their international recognition cases. Uşak University Journal of Social Sciences, 6(2), 259-290. http://dx.doi.org/10.12780/UUSBD164

Ay, Ş. (2005). Critical thinking instruction and Bloom's taxonomy. Abant İzzet Baysal University Journal of Education, 5(2), 164-173.

Ayvac1, H. Ş., \& Türkdoğan, A. (2010). Examination of the written questions of the science and technology course according to the Bloom's restructured taxonomy. Journal of Turkish Science Education, 7(1), 13-25

Bağdat, O., \& Anapa, S. P. (2014). Investigation of the 8th grade students' algebraic thinking skills with SOLO taxonomy.International Journal of Social Sciences, 26, 473-496. http://dx.doi.org/10.9761/JASSS2364.

Barth, J. L., \& Demirtaş, A. (1997). Primary Education Social Studies Learning. Ankara: Ministry of National Education.

Biggs, J. B. (1995). Assessing for learning: some dimensions underlying new approaches to educational assessment. Alberta Journal of Educational Research, 41, 1-18.

Biggs, J. B. (2003). Teaching for Quality Learning at University. Maidenhead: Open University Press.

Biggs, J. B., \& Collis, K. F. (1982). Evaluating the quality of learning the SOLO taxonomy (Structure of the Observed Learning Outcomes). New York: Academic Press, Inc.

Biggs, J. B., \& Collis, K. F. (1991). Multimodal learning and the quality of intelligent behaviour. In: A Helga, H Rowe 
(Eds.). Intelligence, Reconceptualization and Measurement (pp. 57-76). New Jersey: Lawrence Erlbaum Assoc.

Bloom, B. S. (1956). Taxonomy of Educational Objectives, the Classification of Educational Goals, Handbook I: Cognitive Domain. New York: David Mckay Company.

Brabrand, C., \& Dahl, B. (2009). Using the SOLO taxonomy to analyze competence progression of university science curricula. Higher Education, 58(4), 531-549. http://dx.doi.org/10.1007/s10734-009-9210-4

Burnett, P. C. (1999a). Assessing the outcomes of counseling within a learning framework [ERIC Document, ED 432 706]. Paper presented in The Annual Conference of American Educational Research Association, Montreal, Quebec, Canada, April 19 to 23, 1999.

Burnett, P. C. (1999b). Assessing the structure of learning outcomes from counseling using the SOLO taxonomy: an exploratory study. British Journal of Guidance \& Counseling, 27(4), 567-580. http://dx.doi.org/10.1080/03069889908256291

Chan, C., Tsui, M. S., Chan, M., \& Hong, J. (2002). Applying the structure of the observed learning outcomes (SOLO) taxonomy on student's learning outcomes: An empirical study. Assessment \& Evaluation in Higher Education, 27(6), 511-527. http://dx.doi.org/10.1080/0260293022000020282

Demirel, Ö. (2015). Program Development in Education, from Theory to Practice. Ankara: Pegem Akademi.

Dindar, H., \& Demir, M. (2006). Evaluation of fifth grade primary teachers' questions in science exams according to Bloom's taxonomy. Gazi University Journal of Gazi Educational Faculty, 26(3), 87-96.

Erden, M. (2000). Social Studies Teaching. İstanbul: Alkım Yayınevi.

Fink, L. D. (2003) Creating Significant Learning Experiences: An Integrated Approach to Designing College Courses. San Francisco, CA: Jossey-Bass.

Gazel, A. A., \& Erol, H. (2012). A taxonomic analysis of the intended learning outcomes of the primary school social studies curriculum for 7th graders. Journal of Theoretical Educational Science, 5(2), 202-222.

Gelen, İ. (2002). The evaluation of fourth grade elementary school teachers' competences about teaching thinking skills in social studies course. Journal of Çukurova University Institute of Social Sciences, 10(10), 100-119.

Gezer, M., \& İlhan, M. (2014). An evaluation of the assessment questions in the textbook and objectives of the 8th grade curriculum citizenship and democracy education course according to SOLO taxonomy. Eastern Geographical Review, 19(32), 193-207.

Göktepe, S., \& Özdemir, A. Ş. (2013). Examining elementary mathematics teacher candidates' special visualization skills by SOLO model. Kalem International Journal of Educational and Human Sciences, 5, 91-146.

Güler, A., Halıcıoğlu, M. B., \& Taşğın, S. (2013). Qualitative research methods in social sciences. Ankara. Seçkin Yayincilik.

Haladyna, T. M. (1997). Writing test items to evaluate higher-order thinking. Needham Heights, MA: Allyn \& Bacon.

Hattie, J. A., \& Purdie, N. (1994). Using the SOLO taxonomy to classify test items. In B. Dart \& G. Boulton-Lewis (Eds.), Teaching and Learning in Higher Education (pp. 145-176). Melbourne, Aus: ACER.

Keskin, Y. (2002). Analysis and comparison of the social studies teaching programs which have been applied in Turkey since the second constitutional period. Master Thesis, Unpublished. İstanbul: Marmara University.

Keskin, Y. (2008). Values education in social studies teaching programs in Turkey: research on the historical development and efficiency of 1998 and 2004 programs. Ph. D. Thesis, Unpublished. İstanbul: Marmara University.

Koray, Ö., Altunçekiç, A., \& Yaman, S. (2005). Evaluation of candidate Science teachers’ questioning skills according to Bloom's taxonomy. Pamukkale University Journal of Education, 17, 33-39.

Marzano, R. J. (2000). Designing a new taxonomy of educational objectives. Thousand Oaks, CA: Corwin Press.

MEB [National Ministry of Education, NME] (2005). Social Studies Teaching Program. Retrieved from http://programlar.meb.gov.tr

Şenses, A. (2008). Analysis of the questions in primary education 6th grade social studies course books in terms of content validity and Bloom's taxonomy. Master Thesis, Unpublished. Tokat: Gaziosmanpaşa University..

Sönmez, V. (1997). Social studies teaching and teacher guidance. Ankara: Anı Yayıncılık.

Tutkun, Ö. F. (2012). An overview on Bloom's revised taxonomy. Sakarya University Journal of Education, 2(1), 
14-22.

Tutkun, Ö. F., Demirtaş, Z., Arslan, S., \& Gür Erdoğan, D. (2015). General structure of the revised Bloom's taxonomy: Reasons and modifications. International Journal of Social Science, 32, 57-62. http://dx.doi.org/10.9761/JASSS2684

Wong, C. (2007). Views on the adoption and the implementation of the SOLO taxonomy. In S. Franhland (Ed.), Enhancing Teaching and Learning through Assessment: Deriving an Appropriate Model (pp. 4-15). The Netherlands: Springer.

Yıdırım, A., \& Şimşek, H. (2006). Qualitative research methods in social sciences. Ankara: Seçkin Yayıncılık.

Yüksel, S. (2007). New developments and classifications in cognitive domain classification (taxonomy). Türk Ĕ̈itim Bilimleri Dergisi, 5(3), 479-509.

This work is licensed under a Creative Commons Attribution 3.0 License. 